\title{
The Retrovirology Open Access experience Kuan-Teh Jeang
}

\author{
Address: The National Institutes of Health, Bethesda, MD, USA \\ Email: Kuan-Teh Jeang - kjeang@niaid.nih.gov
}

Published: 15 December 2009

Retrovirology 2009, 6:115 doi:10.1186/1742-4690-6-115

This article is available from: http://www.retrovirology.com/content/6/I/II5

(c) 2009 Jeang; licensee BioMed Central Ltd.

This is an Open Access article distributed under the terms of the Creative Commons Attribution License (http://creativecommons.org/licenses/by/2.0), which permits unrestricted use, distribution, and reproduction in any medium, provided the original work is properly cited.
Received: 13 December 2009

Accepted: 15 December 2009

\author{
Abstract \\ The Retrovirology Open Access experience after publishing more than 500 articles is discussed.
}

\section{Editorial}

As 2009 comes to a close, it is instructive to reflect upon Retrovirology's experience with Open Access publishing. The journal was started with two objectives. First, there was a recognition that the robust field of basic retrovirus research could benefit from a dedicated rapid-publication online journal of good quality. Second, there was a desire to build a journal that would be freely accessible in full text to all readers without being restricted by the ability to pay for a subscription.

Retrovirology launched in February 2004 and since then has published more than 550 papers. To maintain a high scientific standard, the journal aims to have no more than 10 articles per month or roughly a total of 120 per year. From 2005 through 2009, Retrovirology has averaged 100 published items per year (Figure 1). The quality of the journal has been monitored stringently by the editors and the editorial board and has improved over time. The latter assertion is supported by several observations. For instance, in November 2004, Retrovirology received 6 submissions and published 5 papers that month. By contrast, in November 2008, Retrovirology received 27 submissions and published 10 papers; and in November 2009, the journal received 29 submissions and published 10 . In parallel, the rate of annual citations to Retrovirology has also increased steadily with a healthy upslope (Figure 1).

Open Access publishing in 2004 was viewed skeptically as a new approach with an uncertain future. In the begin- ning, many colleagues openly questioned whether an Open Access Retrovirology journal could be successful. Five years later, most subscription-based journals now offer their authors an Open Access option, and Retrovirology, as measured by SCImago journal rating http://www.scima gojr.com/ using data from Scopus, ranks in the top quartile of all virology journals. Similarly in data from the Journal Citation Reports of the ISI http://pcs.isiknowl edge.com, Retrovirology has a recent Impact Factor [1] which is closely behind that of the Journal of Virology, and ahead of Virology, the Journal of General Virology, and AIDS Research and Human Retroviruses. The visibility of Retrovirology papers is attested by the citation numbers to recently published papers. For example, two Retrovirology review articles [2,3] published in 2007 and 2008 have already been cited 54 and 33 times, while two 2007 research papers $[4,5]$ have been cited 27 and 23 times. These numbers are competitive with the citation frequencies to articles of similar age and similar topics published in other highly rated journals.

Periodically, emails arrive to me from colleagues in South America and graduate students in Africa conveying thanks for Retrovirology's fee-free full text Open Access format. As the journal's editor-in-chief, I am gratified by these responses. Perhaps on occasions when you are delayed in an airport lounge and need to read the full text of retrovirology papers using your personal lap top computer, you might be similarly gratified that Retrovirology is Open Access. The Retrovirology Open Access experience has been 
Papers per year

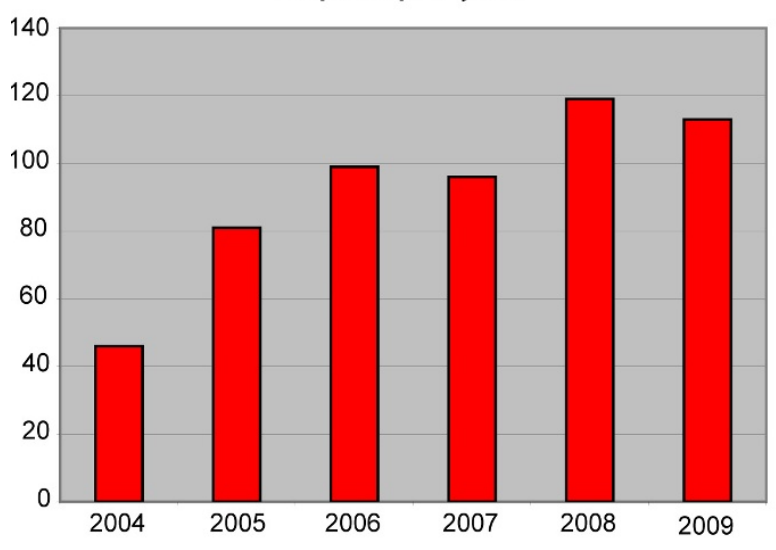

Citations per year

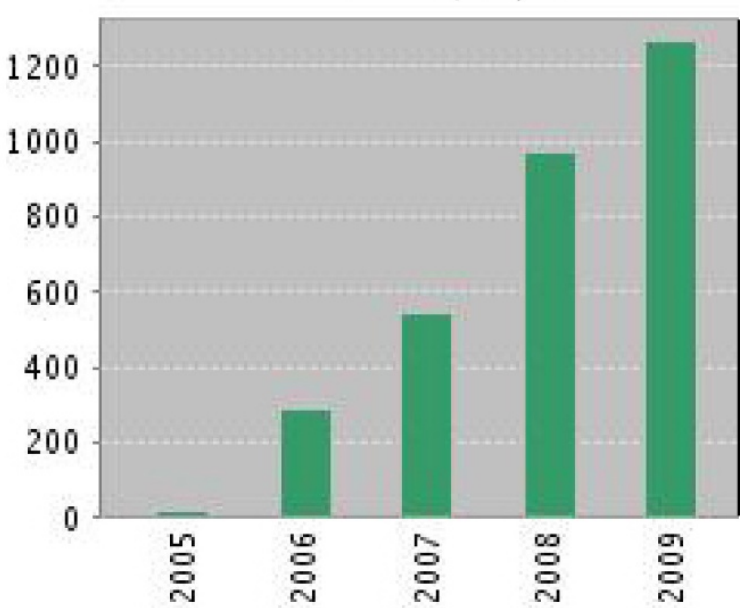

Figure I

Graphic representations of the number of published papers per year (left) and the number of citations to Retrovirology papers per year (right). Citation data are from the ISI Web of Science database. The numbers shown for 2009 are the information available at time of writing of this editorial and are not the final year-end numbers.

good for science, good for authors, and good for readers. The journal is doing well by doing good.

\section{Competing interests}

The author is editor-in-chief of Retrovirology.

\section{Authors' contributions}

KTJ wrote this editorial.

\section{Acknowledgements}

I thank my fellow Retrovirology editors and editorial board members for their service to the journal. I am grateful to Ben Berkhout and Andrew Lever for critical readings of this editorial. The content of this publication reflects the personal opinions of the author and does not necessarily reflect the views or the policies of the US Department of Health and Human Services or the US National Institutes of Health, nor does mention of trade names, commercial products, or organizations imply endorsement by the U.S. Government.

\section{References}

I. Jeang KT: $\mathbf{H}$-index, mentoring-index, highly-cited and highlyaccessed: how to evaluate scientists? Retrovirology 2008, 5:106.

2. Towers G]: The control of viral infection by tripartite motif proteins and cyclophilin A. Retrovirology 2007, 4:40.

3. Goila-Gaur R, Strebel K: HIV-I Vif, APOBEC, and intrinsic immunity. Retrovirology 2008, 5:51.

4. Savarino A: In-Silico docking of HIV-I integrase inhibitors reveals a novel drug type acting on an enzyme/DNA reaction intermediate. Retrovirology 2007, 4:.

5. Lum AM, Wang BB, Li L, Channa N, Bartha G, Wabl M: Retroviral activation of the mir-106a microRNA cistron in $T$ lymphoma. Retrovirology 2007, 4:5.
Publish with Bio Med Central and every scientist can read your work free of charge

"BioMed Central will be the most significant development for disseminating the results of biomedical research in our lifetime. "

Sir Paul Nurse, Cancer Research UK

Your research papers will be:

- available free of charge to the entire biomedical community

- peer reviewed and published immediately upon acceptance

- cited in PubMed and archived on PubMed Central

- yours - you keep the copyright
BiolMedcentral 